\title{
Comparison of the Lower Confidence Limit to the Fixed-Percentage Method for Assessing Airway Obstruction in Routine Clinical Practice
}

\author{
Ashutosh N Aggarwal MD DM, Dheeraj Gupta MD DM, \\ Ritesh Agarwal MD DM, and Surinder K Jindal MD
}

\begin{abstract}
BACKGROUND: Although the statistically derived lower limit of normal (LLN) for the ratio of $\mathrm{FEV}_{1}$ to $\mathrm{FVC}$ is considered superior to a fixed cutoff value (such as 0.70 ) for diagnosing airway obstruction, the fixed-cutoff method continues to be used and advocated. OBJECTIVE: To evaluate the misclassification of spirometrically determined airway obstruction arising from the use of the fixed-percent method, in comparison to the LLN method for FEV $/ F V C$. METHODS: We reviewed 27,307 spirometry records from adult men, and diagnosed airway obstruction based on the LLN (predicted value minus $\mathbf{1 . 6 4 5}$ times the standard error of estimate from a north Indian reference equation for $\mathrm{FEV}_{1} / \mathrm{FVC}$ ) and based on a fixed cutoff of 0.70 . We computed agreement and discordance between the two methods, and determined the sensitivity, specificity, and predictive values of the fixed-percent method in identifying true obstruction. RESULTS: The results were discordant in $1,622$ subjects $(6 \%)$. Overall agreement between the two methods was good (kappa estimate 0.869$)$, but worsened considerably with advancing age. 1,290 subjects $(5 \%)$ who were deemed normal with the LLN method were diagnosed as having airway obstruction with the fixed-percentage method. Overall the sensitivity, specificity, and positive predictive value of the fixed-percentage method were $0.963,0.929$, and 0.871 , respectively. Specificity and positive predictive value decreased sharply with advancing age. CONCLUSIONS: The negative age-dependence of $\mathrm{FEV}_{\mathbf{1}} / \mathrm{FVC}$ results in over-diagnosis of airway obstruction in middle-aged and elderly men, and under-diagnosis in young men, with the fixed-percentage method. Airway obstruction should be assessed with the LLN of FEV I $_{1}$ FVC, with the LLN derived from appropriate reference equations. Key words: airway obstruction; India; obstructive lung diseases; predictive value of tests; reference standards; spirometry. [Respir Care 2011;56(11):1778-1784. () 2011 Daedalus Enterprises]
\end{abstract}

\section{Introduction}

Demonstration of a reduced ratio of $\mathrm{FEV}_{1}$ to $\mathrm{VC}$ (vital capacity) or FVC (forced vital capacity) on spirometry

The authors are affiliated with the Department of Pulmonary Medicine, Postgraduate Institute of Medical Education and Research, Chandigarh, India.

The authors have disclosed no conflicts of interest.

Correspondence: Ashutosh N Aggarwal MD, Department of Pulmonary Medicine, Postgraduate Institute of Medical Education and Research, Chandigarh 160012 India. E-mail: ashutosh@indiachest.org.

DOI: $10.4187 /$ respcare. 01160 remains the universally accepted criterion for diagnosis of airway obstruction in routine clinical practice. Despite this, there is no broad consensus as to how this reduction should be defined. It has been an age-old practice to use a fixed ratio as the cutoff for this purpose. Most commonly, an $\mathrm{FEV}_{1} / \mathrm{VC}$ of less than 0.70 or 0.75 is used to diagnose

See the Related Editorial on Page 1861

obstruction on spirometry. Even though there is no statistical or epidemiological basis for choosing 0.70 (or for that matter any other similar ratio) as a cutoff for this purpose, this practice remains engrained in usage worldwide. 


\section{Lower Confidence Limit Versus Fixed Percentage for Assessing Obstruction}

The problems and errors of using fixed percentages of reference values were pointed out more than 4 decades ago. ${ }^{1}$ It was also proposed that the statistically derived lower limit of normal (LLN) should be preferred over a fixed percentage when interpreting spirometry data. ${ }^{2} \mathrm{We}$ previously found that fixed-percentage cutoffs introduce unacceptable misclassification rates in interpretation of spirometry results. ${ }^{3}$ In an effort to standardize interpretation of lung function tests, the American Thoracic Society proposed its guidelines in 1991, and recommended that airway obstruction should be defined by an $\mathrm{FEV}_{1} / \mathrm{VC}$ (or $\mathrm{FEV}_{1} / \mathrm{FVC}$ ) below a certain LLN. ${ }^{4}$ This LLN could be either the value below the fifth percentile or the lower $95 \%$ confidence limit of the values from a reference population. The American Thoracic Society/European Respiratory Society guidelines published in 2005 , and the more recent recommendations on spirometry in the primary-care setting, have largely reiterated that stand.5,6 However, several old and recent international initiatives, mostly focusing on COPD, still recommend the use of a fixed percentage for this purpose. ${ }^{7-9}$ The Global Initiative for Chronic Obstructive Lung Disease (GOLD) guidelines, first published in 2001 and thereafter updated annually, define COPD as a post-bronchodilator $\mathrm{FEV}_{1} / \mathrm{FVC}$ below $0.70 .{ }^{10}$

Many healthy individuals have an $\mathrm{FEV}_{1} / \mathrm{FVC}$ below 0.70 , and the proportion of such individuals increases with advancing age. ${ }^{11-14}$ It is pertinent to note that a large number of subjects suspected to have COPD are screened in the sixth decade or later. If the GOLD (or such similar) guidelines were universally followed, many healthy individuals could be falsely diagnosed as having obstruction, based on a cutoff value of 0.70 . A review of several published reference equations for $\mathrm{FEV}_{1} / \mathrm{VC}$ clearly shows that, with very few exceptions, the LLN predicted ratio declines to well below 0.70 with advancing age. ${ }^{15,16}$ Although the developers of GOLD guidelines have acknowledged the criticism of their fixed criterion to define airway obstruction, they opined that more population-based data are required to determine outcomes of those found to be obstructed by either or both methods. We planned this study to evaluate the magnitude of difference in spirometrically determined airways obstruction with the fixed-percentage and LLN methods, and to estimate the quantum of misclassification with the fixed-percentage method, in men undergoing routine pulmonary function testing at our institute.

\section{Methods}

The study protocol was approved by our institutional ethics committee. Our pulmonary function laboratory offers spirometry as a routine service in both the out-patient and in-patient sections. Spirometry records are maintained in a computerized database specifically developed for this purpose.${ }^{17}$ For this study we retrospectively analyzed the pulmonary-function-testing records from all men older than 15 years of age who underwent spirometry in January 1999 through December 2008. We included all reports from eligible subjects who had multiple spirometry records. We did not examine the reasons for performing spirometry, or other clinical details (including smoking status and diagnosis).

All subjects had performed spirometry with a dry rolling seal spirometer (Spiro RS232, PK Morgan, Kent, United Kingdom), per standard prevalent spirometry guidelines, assisted by technicians experienced in pulmonary function testing. ${ }^{18,19}$ Spirometer circuit leaks and equipment calibration were frequently checked to ensure performance. For each subject, the highest measurements of FVC and $\mathrm{FEV}_{1}$ from among at least 3 technically acceptable and reproducible maneuvers are expressed at body temperature and pressure saturated with water vapor. An additional slow VC maneuver was not routinely performed. We employed 2 widely used spirometry-based definitions of airway obstruction: a fixed-percentage cutoff of $\mathrm{FEV}_{1}$ / FVC $<0.70$, and the LLN, computed as the difference between the predicted value and 1.645 times the standard error of estimate of the reference equation for $\mathrm{FEV}_{1} / \mathrm{VC}$ in use at our institute. ${ }^{17,20}$ These equations were generated from spirometry studies performed on 962 healthy nonsmoking north Indian adults, ages 15-74 years, with a water-seal spirometer. This LLN cutoff represents the lower $5 \%$ confidence limit, and is equivalent to the fifth percentile of values in the reference population. Spirometry records that showed an $\mathrm{FEV}_{1} / \mathrm{FVC}$ less than the LLN were classified as having an obstructive pattern.

We stratified the subjects into 5-year age groups and computed the prevalence of obstruction and the proportion of discordant results for each group. We calculated the agreement on obstruction diagnosis with the kappa estimate. We used the LLN definition as the reference standard to identify true obstruction..$^{4,5}$ The proportion of results wrongly classified as having an obstructive defect using the fixed-percent method was accordingly estimated. We also calculated the sensitivity, specificity, and positive and negative predictive values of the fixed-percent method in identifying true obstruction.

\section{Results}

During the study period, 28,221 male subjects underwent spirometry. We excluded 30 records because of incomplete data, and 884 records because the individuals were $\leq 15$ years old, so 27,307 records formed the data set for the analysis. For the analyzed cohort, the mean \pm SD height was $166 \pm 7 \mathrm{~cm}$, and the mean $\pm \mathrm{SD}$ age was $48 \pm 16$ years. 18,339 subjects $(67 \%)$ were older than 40 years, and the eldest was 95 years old (Table 1). 


\section{Lower Confidence Limit Versus Fixed Percentage for Assessing Obstruction}

Table 1. Prevalence of Spirometrically Determined Airway Obstruction, and Performance of the Fixed-Percentage Method Versus the LowerLimit-of-Normal Method

\begin{tabular}{|c|c|c|c|c|c|c|c|c|}
\hline \multirow{2}{*}{$\begin{array}{l}\text { Age } \\
\text { Range } \\
(y)\end{array}$} & \multirow{2}{*}{$\begin{array}{l}\text { Number } \\
\text { of } \\
\text { Subjects }\end{array}$} & \multicolumn{2}{|c|}{ Obstruction Diagnosis (\%) } & \multirow[b]{2}{*}{$\begin{array}{l}\text { Agreement } \\
\text { (kappa) }\end{array}$} & \multirow[b]{2}{*}{ Sensitivity } & \multirow[b]{2}{*}{ Specificity } & \multirow{2}{*}{$\begin{array}{c}\text { Predictive } \\
\text { Value of } \\
\text { Positive Test }\end{array}$} & \multirow{2}{*}{$\begin{array}{c}\text { Predictive } \\
\text { Value of } \\
\text { Negative Test }\end{array}$} \\
\hline & & $\begin{array}{l}\text { LLN } \\
\text { Method }\end{array}$ & $\begin{array}{l}\text { Fixed- } \\
\text { Percentage } \\
\text { Method }\end{array}$ & & & & & \\
\hline $16-20$ & 1,218 & 21 & 14 & 0.759 & 0.664 & 1.000 & 1.000 & 0.920 \\
\hline $21-25$ & 1,622 & 25 & 18 & 0.800 & 0.725 & 1.000 & 1.000 & 0.918 \\
\hline $26-30$ & 1,844 & 23 & 19 & 0.887 & 0.836 & 1.000 & 1.000 & 0.953 \\
\hline $31-35$ & 1,985 & 25 & 23 & 0.936 & 0.907 & 1.000 & 1.000 & 0.969 \\
\hline $36-40$ & 2,299 & 28 & 28 & 0.958 & 0.966 & 0.990 & 0.973 & 0.987 \\
\hline $41-45$ & 2,476 & 30 & 33 & 0.949 & 1.000 & 0.968 & 0.932 & 1.000 \\
\hline $46-50$ & 3,144 & 35 & 39 & 0.928 & 1.000 & 0.948 & 0.914 & 1.000 \\
\hline $51-55$ & 3,051 & 37 & 41 & 0.909 & 1.000 & 0.931 & 0.894 & 1.000 \\
\hline $56-60$ & 3,101 & 38 & 45 & 0.849 & 1.000 & 0.882 & 0.836 & 1.000 \\
\hline $61-65$ & 2,615 & 41 & 50 & 0.804 & 1.000 & 0.836 & 0.805 & 1.000 \\
\hline $66-70$ & 1,959 & 43 & 54 & 0.783 & 1.000 & 0.808 & 0.796 & 1.000 \\
\hline $71-75$ & 1,139 & 39 & 52 & 0.746 & 1.000 & 0.790 & 0.753 & 1.000 \\
\hline $76-80$ & 575 & 35 & 51 & 0.682 & 1.000 & 0.755 & 0.685 & 1.000 \\
\hline $81-85$ & 206 & 40 & 54 & 0.723 & 1.000 & 0.766 & 0.739 & 1.000 \\
\hline $86-90$ & 53 & 26 & 42 & 0.672 & 1.000 & 0.795 & 0.636 & 1.000 \\
\hline 91-95 & 20 & 25 & 50 & 0.500 & 1.000 & 0.667 & 0.500 & 1.000 \\
\hline Total & 27,307 & 33 & 37 & 0.869 & 0.963 & 0.929 & 0.871 & 0.981 \\
\hline
\end{tabular}

In all, 16,999 subjects (62\%) had no evidence of airways obstruction by either method, 8,686 subjects (32\%) had an obstructive pattern by both definitions, and 1,622 subjects (6\%) had discordant results. Of those 1,622, 1,290 (5\%) had an obstructive pattern only with the 0.70 cutoff, and all these subjects were older than 35 years (Fig. 1). Another 332 subjects (1\%) had obstruction only with the LLN definition, and all of these subjects were $\leq 40$ years old (see Fig. 1). Overall agreement between the 2 methods was good: the kappa estimate was $0.869 \pm 0.003$ (standard error) for the entire cohort. On detailed analysis, this agreement was good only in the age group 26-65 years, and the misclassification progressively worsened with advancing age (see Table 1 and Fig. 1).

For the entire cohort, the sensitivity, specificity, positive predictive value, and negative predictive value of the fixedpercent method were $0.963,0.929,0.871$, and 0.981 , respectively. The sensitivity of the fixed-percentage method in picking up airway obstruction was excellent from the fifth decade onwards (see Table 1), but the specificity and positive predictive value were poor in that age group, and progressively worsened with advancing age (see Table 1).

\section{Discussion}

A person's $\mathrm{FEV}_{1} / \mathrm{FVC}$ is an individual value that depends, among other factors, on sex and age. Because of this, it is almost impossible to accurately predict an individual's normal $\mathrm{FEV}_{1} / \mathrm{FVC}$. For epidemiological and clin-

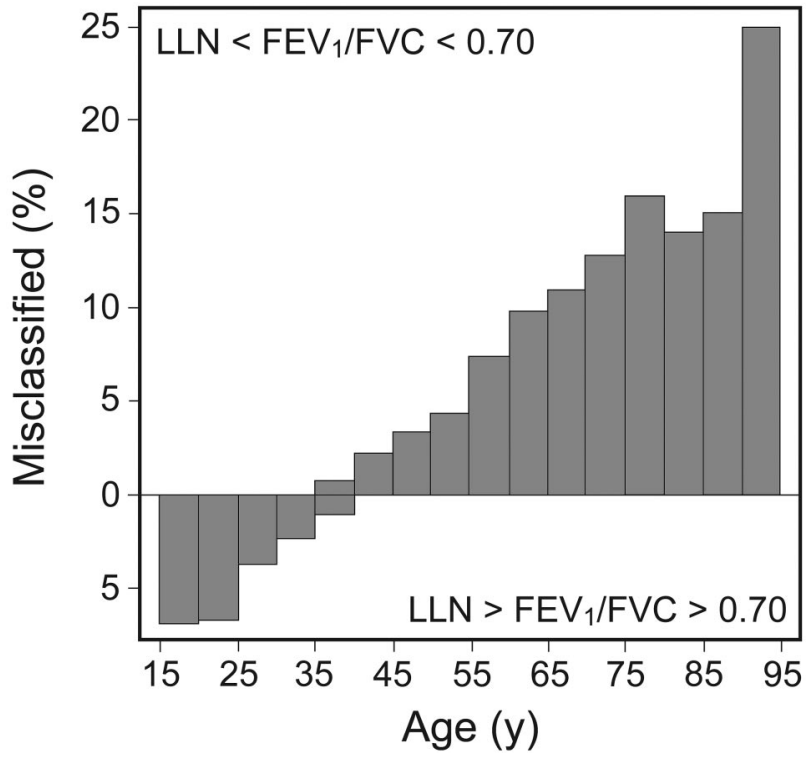

Fig. 1. Mistakes in diagnosis of airway obstruction based on an $\mathrm{FEV}_{1} / \mathrm{FVC}<0.70$ versus based on the statistically derived lower limit of normal (LLN) as the accepted standard for diagnosis.

ical purposes we generally rely on reference values derived from observations on apparently healthy individuals from the general population. These statistically derived values take into account age, sex, and body habitus, and provide a lower estimate of the range of normal. Use of the LLN derived from regression equations provides a kind of floating estimate of obstruction. Although this method is 


\section{Lower Confidence Limit Versus Fixed Percentage for Assessing Obstruction}

not a perfect solution, it is certainly much better in statistical terms for identifying a truly decreased $\mathrm{FEV}_{1} / \mathrm{FVC}$ value. LLN-based estimates are clearly superior to any arbitrary fixed cutoff value (eg, 0.70 ) for discriminating healthy from diseased individuals. More recently, an innovative lambda-mu-sigma method was proposed, which defines the LLN for $\mathrm{FEV}_{1} / \mathrm{FVC}$ as the fifth percentile of the distribution of $\mathrm{Z}$ scores. Data from 3,502 American subjects ages $40-80$ years suggested that $\mathrm{FEV}_{1} / \mathrm{FVC}$ below the LLN thus computed identifies individuals with a higher risk of death and higher prevalence of respiratory symptoms, which supports the use of that threshold for diagnosing COPD. ${ }^{21}$ However, that novel statistical method still needs validation in other studies.

Some healthy persons have $\mathrm{FEV}_{1} / \mathrm{FVC}$ below 0.70 , and the proportion of such individuals increases with advancing age. ${ }^{15}$ In a population-based study in north Italy, spirometry was performed on 1,727 adults ages $25-73$ years, of whom $40 \%$ had an $\mathrm{FEV}_{1} / \mathrm{FVC}$ less than 0.75 , and $18 \%$ had an $\mathrm{FEV}_{1} / \mathrm{FVC}$ less than 0.70.11 "Abnormal" $\mathrm{FEV}_{1} /$ FVC was more frequent in men, smokers, and people older than 45 years. In a study with nearly 4,000 elderly subjects in Norway, $21 \%$ of the men and $17 \%$ of the women ages $60-69$ years, and $38 \%$ of the men and $26 \%$ of the women $>70$ years old, had $\mathrm{FEV}_{1}$ /VC less than $0.70 .{ }^{12}$ Another report on 71 asymptomatic Norwegian never-smokers $>70$ years old found $\mathrm{FEV}_{1} / \mathrm{FVC}$ below 0.70 in $35 \%$ of the total sample, and in $50 \%$ of the subjects $>80$ years old. ${ }^{13}$ In the primary-care setting, the use of a fixed-percentage cutoff clearly leads to over-diagnosis of COPD in elderly subjects, and to under-diagnosis in young subjects, and should hence be avoided. ${ }^{6}$

The $\mathrm{FEV}_{1} / \mathrm{FVC}$ reference equations we use at our center are based on age and height as dependent variables, and $\mathrm{FEV}_{1} / \mathrm{FVC}$ decreases with increasing height and advancing age. ${ }^{17,20}$ In a north Indian man $>40$ years old, the measured $\mathrm{FEV}_{1} / \mathrm{FVC}$ can be below 0.70 but still above the LLN for his age and height. Per standard recommendations for spirometry interpretation, he would not have an obstructive defect, but would be diagnosed as having obstruction using the GOLD criterion..$^{5,10}$ A large number of subjects suspected to have COPD are screened in the sixth decade or later. If the GOLD guidelines were routinely followed, many of them could be falsely diagnosed as having obstruction, based on a cutoff value of 0.70 . Clearly, therefore, the 0.70 cutoff tends to overestimate obstruction in the age group in whom it is most crucial to diagnose or rule out COPD. The 0.70 cutoff underestimates obstruction in younger individuals, in whom the LLN of $\mathrm{FEV}_{1}$ / FVC is considerably higher than 0.70 (Fig. 2), and in whom an $\mathrm{FEV}_{1} / \mathrm{FVC}$ above 0.70 could be associated with true airway obstruction.

Several investigators have documented a high misclassification rate with the fixed-cutoff criterion in both healthy

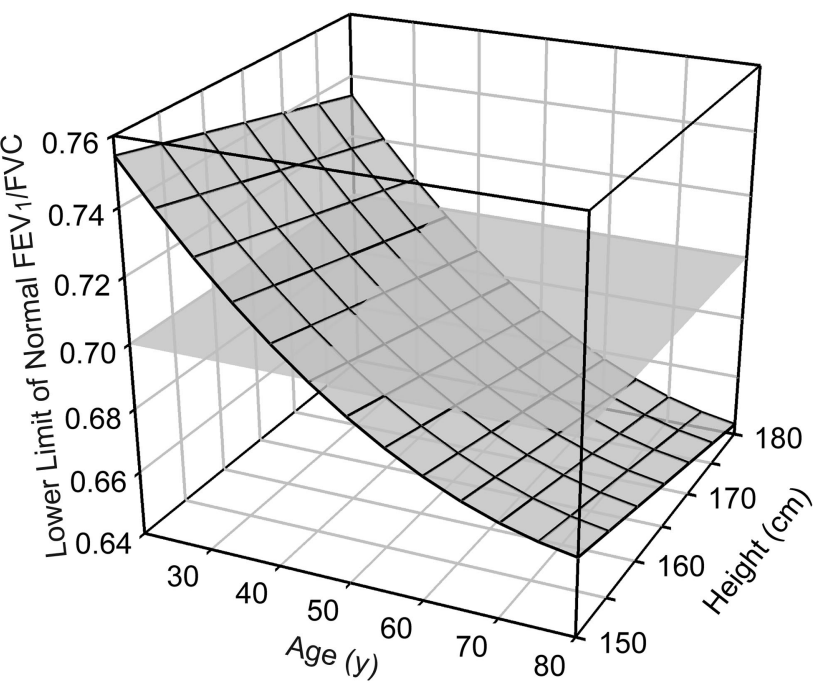

Fig. 2. Lower limit of normal for $\mathrm{FEV}_{1} / \mathrm{FVC}$ as a function of age and height in north Indian men. See Reference 17 for details on the reference equation used.

individuals and patients (Table 2). ${ }^{14,22-31}$ Substantial misclassification was also reported with the fixed-percentage criterion in an analysis of 815 young adults $(<45$ years old) with asthma in the European Community Respiratory Health Survey database. ${ }^{32}$ The 0.70 criteria had $77 \%$ sensitivity and $100 \%$ specificity among men, and $57 \%$ sensitivity and $100 \%$ specificity among women. Our results closely approximate the findings of a recent analysis of spirometric data from 14,056 Dutch subjects (both men and women) in a primary-care setting. ${ }^{33}$ The overall sensitivity, specificity, positive predictive value, and negative predictive value of the fixed 0.70 cutoff, relative to the LLN cutoff definition, were $0.979,0.912,0.720$, and 0.995 , respectively, in that study. Similar to our observations, there was a steady increase in false positive results with advancing age; false positives exceeded $15 \%$ in subjects $>70$ years old. As spirometry is designed to aid diagnosis, rather than exclusion, of obstruction, the low positive predictive value of the 0.70 fixed cutoff in our findings clearly exposes the limitation of the 0.70 fixed cutoff in routine clinical practice.

The $0.70 \mathrm{FEV}_{1} / \mathrm{FVC}$ cutoff therefore cannot be applied as a general "rule of thumb" in the general population, because it yields false negatives in young adults and false positives in older individuals. Mathematical complexities and lack of appropriate reference equations have often been proposed as reasons that physicians and researchers opt for the simpler fixed-percentage criterion. But these certainly are not such great problems that they justify the huge health costs associated with misdiagnosis of airway obstruction in a rather large proportion of our adult population. In fact, most modern computerized and program- 


\section{Lower Confidence Limit Versus Fixed Percentage for Assessing Obstruction}

Table 2. Recent Studies on Spirometric Diagnosis of Airway Obstruction

\begin{tabular}{|c|c|c|c|c|c|}
\hline $\begin{array}{l}\text { First } \\
\text { Author }\end{array}$ & Year & Study Population & $\begin{array}{c}\text { Age } \\
\text { Range (y) }\end{array}$ & $\begin{array}{c}\text { Definitions and Prevalence of } \\
\text { Airway Obstruction }\end{array}$ & Notes \\
\hline Celli $^{22}$ & 2003 & $\begin{array}{l}\text { 9,838 adults from } \\
\text { NHANES III } \\
\text { database }\end{array}$ & $30-80$ & $\begin{array}{l}\mathrm{FEV}_{1} / \mathrm{FVC}<0.70: 18 \% \\
\mathrm{FEV}_{1} / \mathrm{FVC}<\mathrm{LLN}: 16 \%\end{array}$ & $\begin{array}{l}\text { Fixed-ratio method overestimated airway } \\
\text { obstruction by more than } 1.5 \text { times in adults } \\
\geq 60 \mathrm{y} \text { old }\end{array}$ \\
\hline Hnizdo $^{23}$ & 2006 & $\begin{array}{l}\text { 13,842 adults from } \\
\text { NHANES III } \\
\text { database }\end{array}$ & $20-80$ & $\begin{array}{l}\mathrm{FEV}_{1} / \mathrm{FVC}<0.70 \text { and } \mathrm{FEV}_{1} \\
\geq 80 \% \text { predicted: } 14 \% \\
\mathrm{FEV}_{1} / \mathrm{FVC}<\mathrm{LLN} \text { and } \mathrm{FEV}_{1} \\
\quad<100 \% \text { predicted: } 12 \% \\
\mathrm{FEV}_{1} / \mathrm{FVC}<0.70 \text { and } \mathrm{FEV}_{1} \\
\quad<80 \% \text { predicted: } 7 \% \\
\mathrm{FEV}_{1} / \mathrm{FVC}<\mathrm{LLN} \text { and } \mathrm{FEV}_{1} \\
\quad<\mathrm{LLN}: 6 \%\end{array}$ & $\begin{array}{l}\text { With the fixed-ratio method the percentages of } \\
\text { individuals classified as having mild or } \\
\text { moderate COPD were } 58 \% \text { and } 37 \% \text { higher, } \\
\text { respectively, in the 50-80 y age category. }\end{array}$ \\
\hline Roberts $^{24}$ & 2006 & $\begin{array}{l}\text { 1,503 hospitalized } \\
\text { patients in } \\
\text { Indianapolis }\end{array}$ & $\begin{array}{r}<20 \text { to } \\
>90\end{array}$ & $\begin{array}{l}\mathrm{FEV}_{1} / \mathrm{FVC}<0.70: 40 \% \\
\mathrm{FEV}_{1} / \mathrm{FVC}<\mathrm{LLN} \text { of Crapo } \\
\quad \text { equation: } 43 \% \\
\mathrm{FEV}_{1} / \mathrm{FVC}<\mathrm{LLN} \text { of } \\
\text { Hankinson equation: } 37 \%\end{array}$ & $\begin{array}{l}8 \% \text { discordant results (via Hankinson equation), } \\
\text { with much higher values at extremes of age } \\
\text { (16\% in subjects } \geq 75 \mathrm{y} \text { old })\end{array}$ \\
\hline Hansen $^{25}$ & 2007 & $\begin{array}{l}\text { 5,906 smokers and } \\
\text { 3,497 nonsmokers } \\
\text { from NHANES III } \\
\text { database }\end{array}$ & $20-80$ & $\begin{array}{l}\mathrm{FEV}_{1} / \mathrm{FVC}<0.70 \\
\mathrm{FEV}_{1} / \mathrm{FVC}<\mathrm{LLN}\end{array}$ & $\begin{array}{l}\text { Nearly half of young adults with airway } \\
\text { obstruction misclassified as normal, and one } \\
\text { fifth of normal older adults misclassified as } \\
\text { having airway obstruction }\end{array}$ \\
\hline Shirtcliffe $^{26}$ & 2007 & $\begin{array}{l}749 \text { adults in New } \\
\text { Zealand }\end{array}$ & $25-74$ & $\begin{array}{l}\mathrm{FEV}_{1} / \mathrm{FVC}<0.70: 16 \% \\
\mathrm{FEV}_{1} / \mathrm{FVC}<\mathrm{LLN}: 10 \%\end{array}$ & $\begin{array}{l}\text { Higher age-adjusted prevalence of airway } \\
\text { obstruction ( } 9 \% \text { via LLN criterion, } 14 \% \text { via } \\
\text { fixed-ratio criterion) in subjects } \geq 40 \text { y old }\end{array}$ \\
\hline $\mathrm{Lau}^{27}$ & 2008 & $\begin{array}{l}525 \text { asymptomatic } \\
\text { male smokers in } \\
\text { Hong Kong }\end{array}$ & $18-80$ & $\begin{array}{l}\mathrm{FEV}_{1} / \mathrm{FVC}<0.70: 14 \% \\
\mathrm{FEV}_{1} / \mathrm{FVC}<\mathrm{LLN}: 19 \%\end{array}$ & $\begin{array}{l}\text { Airway obstruction prevalence increased from } \\
18 \% \text { via LLN criterion, to } 45 \% \text { via fixed-ratio } \\
\text { criterion in the } 60-80 \text { y age group }\end{array}$ \\
\hline Vollmer $^{14}$ & 2009 & $\begin{array}{l}\text { 10,001 adults from } \\
14 \text { countries in the } \\
\text { Burden of } \\
\text { Obstructive Lung } \\
\text { Disease (BOLD) } \\
\text { study }\end{array}$ & $\geq 40$ & $\begin{array}{l}\text { The fixed-ratio method produced } \\
\text { overall estimates of airway } \\
\text { obstruction that, for each site, } \\
\text { were about } 5 \% \text { greater than } \\
\text { with the LLN method. }\end{array}$ & $\begin{array}{l}\text { LLN method reduced the age-related increase in } \\
\text { prevalence of airway obstruction with the } \\
\text { fixed-ratio criterion }\end{array}$ \\
\hline Hwang $^{28}$ & 2009 & $\begin{array}{l}2,728 \text { adults in } \\
\text { Korea }\end{array}$ & $\begin{array}{l}18 \text { to } \\
\quad>75\end{array}$ & $\begin{array}{l}\mathrm{FEV}_{1} / \mathrm{FVC}<0.70: 7 \% \\
\text { FEV }_{1} / \mathrm{FVC}<\text { LLN: } 9 \%\end{array}$ & $\begin{array}{l}\text { Age-adjusted standardized prevalence of airway } \\
\text { obstruction was } 11 \% \text { via LLN criterion vs } 16 \% \\
\text { via fixed-ratio criterion, with maximum } \\
\text { difference among subjects }>65 \text { y old ( } 15 \% \text { vs } \\
31 \%)\end{array}$ \\
\hline Szanto $^{29}$ & 2010 & $\begin{array}{l}574 \text { adults in } \\
\text { Sweden }\end{array}$ & $60-93$ & $\begin{array}{l}\mathrm{FEV}_{1} / \mathrm{FVC}<0.70: 23 \% \\
\mathrm{FEV}_{1} / \mathrm{FVC}<\mathrm{LLN}: 10 \%\end{array}$ & $\begin{array}{l}16 \% \text { of never-smokers were classified as having } \\
\text { obstruction with the fixed-ratio criterion, } \\
\text { compared to } 5 \% \text { with the LLN criterion }\end{array}$ \\
\hline Brazzale $^{30}$ & 2010 & $\begin{array}{l}\text { 1,108 Australian } \\
\text { adults who } \\
\text { underwent lung- } \\
\text { function testing }\end{array}$ & $>20$ & $\begin{array}{l}\text { In subjects }<50 \text { y old: } \\
\mathrm{FEV}_{1} / \mathrm{FVC}<0.70: 19 \% \\
\mathrm{FEV}_{1} / \mathrm{FVC}<<\text { LLN: } 21 \% \\
\text { In } \text { subjects }>65 \text { y old: } \\
\mathrm{FEV}_{1} / \mathrm{FVC}<0.70: 48 \% \\
\mathrm{FEV}_{1} / \mathrm{FVC}<\mathrm{LLN}: 34 \%\end{array}$ & $\begin{array}{l}28 \% \text { persons }>65 \text { y old were falsely diagnosed } \\
\text { as having obstruction, and } 14 \% \text { persons } \\
<50 \text { y were falsely interpreted as having } \\
\text { no obstruction, with the fixed-ratio criterion }\end{array}$ \\
\hline Miller $^{31}$ & 2011 & $\begin{array}{l}\text { 11,413 adults who } \\
\text { underwent lung- } \\
\text { function testing in } \\
\text { United States, } \\
\text { United Kingdom, } \\
\text { and New Zealand }\end{array}$ & $\begin{array}{r}<30 \text { to } \\
>85\end{array}$ & $\begin{array}{l}\mathrm{FEV}_{1} / \mathrm{FVC}<0.70: 36 \% \\
\mathrm{FEV}_{1} / \mathrm{FVC}<\text { LLN: } 28 \%\end{array}$ & $\begin{array}{l}>20 \% \text { of men }>75 \text { y old were falsely } \\
\text { diagnosed as having obstruction with the fixed- } \\
\text { ratio criterion. }\end{array}$ \\
\hline $\begin{array}{l}\text { Present } \\
\text { study }\end{array}$ & 2011 & $\begin{array}{l}27,307 \text { men who } \\
\text { underwent lung- } \\
\text { function testing in } \\
\text { north India }\end{array}$ & $16-95$ & $\begin{array}{l}\mathrm{FEV}_{1} / \mathrm{FVC}<0.70: 37 \% \\
\mathrm{FEV}_{1} / \mathrm{FVC}<\mathrm{LLN}: 33 \%\end{array}$ & See text \\
\hline
\end{tabular}




\section{Lower Confidence Limit Versus Fixed Percentage for Assessing Obstruction}

mable spirometers routinely provide LLN values for all the variables reported.

\section{Limitations}

Our analysis, though it included a large number of subjects, is not entirely without limitations. For one, our study's retrospective nature did not allow us to further evaluate patient-related factors such as clinical diagnosis or smoking status. Although we strive to meet standard performance criteria in all spirometry, our retrospective analysis did not allow us to examine individual test quality, so we could not provide exact details on the proportion of tests that met the spirometry performance criteria. Moreover, during the 10-year data-collection period there were minor changes in the recommendations on spirometry performance. For instance, during the first few years we used the then-prevalent between-maneuver FEV $\mathrm{F}_{1}$ and FVC reproducibility threshold of $0.2 \mathrm{~L} .{ }^{18}$ Later the reproducibility goal was changed to $0.15 \mathrm{~L}$, per the revised American Thoracic Society/European Respiratory Society recommendations. ${ }^{19}$ These and other changes in practice might have introduced important changes in the quality of our spirometry records. Again, because the study was retrospective, we cannot ensure conformity to the current guidelines.

Post-bronchodilator spirometry values were available for only a few subjects, and were therefore not examined. This might have affected our results vis-à-vis the GOLD guidelines, which recommend using post-bronchodilator spirometry results to diagnose airway obstruction. However, we did not aim at suggesting a diagnosis of COPD among the subjects studied, but rather looked at identification of an obstructive defect on spirometry. Additionally, we did not have data on smoking habits and clinical features from some subjects, which would have been essential to consider a diagnosis of COPD. We chose to study only men, because our corresponding reference equations for women yield poor results in the elderly, possibly as a result of poor representation of this age group in the study population from which our reference equations were derived. ${ }^{34}$ Our observations are also derived from a database of men who were referred for spirometry, which indicates a higher pretest probability of abnormal lung function. Hence, our estimates on the prevalence of obstruction cannot be extrapolated to a population or a primary-care setting. Nonetheless, the large number of subjects we studied, with adequate representation of age groups, improves the robustness of our findings.

\section{Conclusions}

Our results suggest a substantial negative age-dependence of $\mathrm{FEV}_{1} / \mathrm{FVC}$, which leads to over-diagnosis of air- way obstruction in middle-aged and elderly men, and under-diagnosis in young men, as compared to the standard LLN criterion. There is a need to rethink the method of identifying airway obstruction to avoid sacrificing proper diagnosis for simplicity, especially in the primary-care setting. Airway obstruction should be defined with an $\mathrm{FEV}_{1} / \mathrm{VC}$ below the LLN, derived from an appropriate reference equation, and not by any fixed, arbitrary cutoff.

\section{REFERENCES}

1. Sobol BJ. Assessment of ventilatory abnormality in the asymptomatic subject: an exercise in futility. Thorax 1966;21(5):445-449.

2. Miller MR, Pincock AC. Predicted values: how should we use them? Thorax 1988;43(4):265-267.

3. Aggarwal AN, Gupta D, Behera D, Jindal SK. Comparison of fixed percentage method and lower confidence limits for defining limits of normality for interpretation of spirometry. Respir Care 2006;51(7): 737-743.

4. American Thoracic Society. Lung function testing: selection of reference values and interpretative strategies. Am Rev Respir Dis 1991; 144(5):1202-1218.

5. Pellegrino R, Viegi G, Brusasco V, Crapo RO, Burgos F, Casaburi $\mathrm{R}$, et al. Interpretative strategies for lung function tests. Eur Respir $\mathrm{J}$ 2005;26(5):948-968.

6. Levy ML, Quanjer PH, Booker R, Cooper BG, Holmes S, Small I. Diagnostic spirometry in primary care: proposed standards for general practice compliant with American Thoracic Society and European Respiratory Society recommendations: a General Practice Airways Group (GPIAG) document, in association with the Association for Respiratory Technology \& Physiology (ARTP) and Education for Health. Prim Care Respir J 2009;18(3):130-147.

7. American Thoracic Society. Evaluation of impairment/disability secondary to respiratory disorders. Am Rev Respir Dis 1986;133(6): 1205-1209.

8. BTS guidelines for the management of chronic obstructive pulmonary disease. The COPD. Guidelines Group of the Standards of Care Committee of the BTS. Thorax 1997;52(Suppl 5):S1-S28.

9. Celli BR, MacNee W. Standards for the diagnosis and treatment of patients with COPD: a summary of the ATS/ERS position paper. Eur Respir J 2004;23(6):932-946.

10. Global Initiative for Chronic Obstructive Lung Disease (GOLD). Global Strategy for Diagnosis, Management and Prevention of COPD. Updated December 2010. http://www.goldcopd.org/guidelines-global-strategy-for-diagnosis-management.html. Accessed September 7, 2011.

11. Viegi G, Pedreschi M, Pistelli F, Di Pede F, Baldacci S, Carrozzi L, et al. Prevalence of airways obstruction in a general population: European Respiratory Society vs American Thoracic Society definition. Chest 2000;117(5 Suppl 2):339S-345S.

12. Medbo A, Melbye H. Lung function testing in the elderly: can we still use $\mathrm{FEV}_{1} / \mathrm{FVC}<70 \%$ as a criterion of COPD? Respir Med 2007;101(6):1097-1105.

13. Hardie JA, Buist AS, Vollmer WM, Ellingsen I, Bakke PS, Morkve O. Risk of over-diagnosis of COPD in asymptomatic elderly neversmokers. Eur Respir J 2002;20(5):1117-1122.

14. Vollmer WM, Gislason T, Burney P, Enright PL, Gulsvik A, Kocabas A, et al. Comparison of spirometry criteria for the diagnosis of COPD: results from the BOLD study. Eur Respir J 2009;34(3):588597.

15. Swanney MP, Ruppel G, Enright PL, Pedersen OF, Crapo RO, Miller $\mathrm{MR}$, et al. Using the lower limit of normal for the $\mathrm{FEV}_{1} / \mathrm{FVC}$ ratio 


\section{Lower Confidence Limit Versus Fixed Percentage for Assessing Obstruction}

reduces the misclassification of airway obstruction. Thorax 2008; 63(12):1046-1051.

16. Quanjer PH. Who has COPD? $\mathrm{FEV}_{1} \%$ predected versus lower limit of normal for $\mathrm{FEV}_{1}$. http://www.spirxpert.com/controversies/ controversy1.html. Accessed September 7, 2011.

17. Aggarwal AN, Gupta D, Jindal SK. Development of a simple computer program for spirometry interpretation. J Assoc Physicians India 2002;50:567-570.

18. American Thoracic Society. Standardization of spirometry, 1994 update. Am J Respir Crit Care Med 1995;152(3):1107-1136.

19. Miller MR, Hankinson J, Brusasco V, Burgos F, Casaburi R, Coates A, et al. Standardisation of spirometry. Eur Respir J 2005;26(2):319-338.

20. Jindal SK, Wahi PL. Pulmonary function laboratory in the tropics: needs, problems and solutions. In: Sharma OP, editor. Lung disease in the tropics. New York: Marcel Dekker, 1991;523-542.

21. Vaz Fragoso CA, Concato J, McAvay G, Van Ness PH, Rochester $\mathrm{CL}$, Yaggi HK, et al. The ratio of $\mathrm{FEV}_{1}$ to $\mathrm{FVC}$ as a basis for establishing chronic obstructive pulmonary disease. Am J Respir Crit Care Med 2010;181(5):446-451.

22. Celli BR, Halbert RJ, Isonaka S, Schau B. Population impact of different definitions of airway obstruction. Eur Respir J 2003;22(2): 268-273.

23. Hnizdo E, Glindmeyer HW, Petsonk EL, Enright P, Buist AS. Case definitions for chronic obstructive pulmonary disease. COPD 2006; 3(2):95-100

24. Roberts SD, Farber MO, Knox KS, Phillips GS, Bhatt NY, Mastronarde JG, et al. $\mathrm{FEV}_{1} / \mathrm{FVC}$ ratio of $70 \%$ misclassifies patients with obstruction at the extremes of age. Chest 2006;130(1):200-206.

25. Hansen JE, Sun XG, Wasserman K. Spirometric criteria for airway obstruction: use percentage of $\mathrm{FEV}_{1} / \mathrm{FVC}$ ratio below the fifth percentile, not $<70 \%$. Chest 2007;131(2):349-355.
26. Shirtcliffe P, Weatherall M, Marsh S, Travers J, Hansell A, McNaughton A, et al. COPD prevalence in a random population survey: a matter of definition. Eur Respir J 2007;30(2):232-239.

27. Lau AC, Ip MS, Lai CK, Choo KL, Tang KS, Yam LY, et al. Variability of the prevalence of undiagnosed airflow obstruction in smokers using different diagnostic criteria. Chest 2008;133(1):4248.

28. Hwang YI, Kim CH, Kang HR, Shin T, Park SM, Jang SH, et al. Comparison of the prevalence of chronic obstructive pulmonary disease diagnosed by lower limit of normal and fixed ratio criteria. $\mathbf{J}$ Korean Med Sci 2009;24(4):621-626.

29. Szanto O, Montnemery P, Elmstahl S. Prevalence of airway obstruction in the elderly: results from a cross-sectional spirometric study of nine age cohorts between the ages of 60 and 93 years. Prim Care Respir J 2010;19(3):231-236.

30. Brazzale DJ, Upward AL, Pretto JJ. Effects of changing reference values and definition of the normal range on interpretation of spirometry. Respirology 2010;15(7):1098-1103.

31. Miller MR, Quanjer PH, Swanney MP, Ruppel G, Enright PL. Interpreting lung function data using $80 \%$ predicted and fixed thresholds misclassifies more than $20 \%$ of patients. Chest 2011;139(1):5259.

32. Cerveri I, Corsico AG, Accordini S, Cervio G, Ansaldo E, Grosso A, et al. What defines airflow obstruction in asthma? Eur Respir J 2009;34(3):568-573.

33. Schermer TR, Smeele IJ, Thoonen BP, Lucas AE, Grootens JG, van Boxem TJ, et al. Current clinical guideline definitions of airflow obstruction and COPD overdiagnosis in primary care. Eur Respir $\mathbf{J}$ 2008;32(4):945-952.

34. Culver BH. Interpretation of spirometry: we can do better than the GOLD standard. Respir Care 2006;51(7):719-721.

This article is approved for Continuing Respiratory Care Education credit. For information and to obtain your CRCE

(free to AARC members) visit www.RCJournal.com

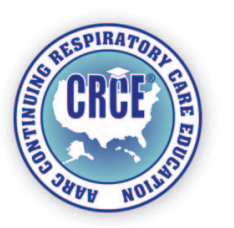

